\begin{tabular}{|l|l|}
\hline $\begin{array}{l}\text { 2. To: (Receiving Organization) } \\
\text { Distribution }\end{array}$ & $\begin{array}{l}\text { 3. From: (originating Organization) } \\
300 \text { Area Stabilization } \\
\text { Project, BWHC }\end{array}$ \\
\hline $\begin{array}{l}\text { 5. Proj./Prog./Dept./Div.: } \\
\text { 300 Area Stabilization }\end{array}$ & $\begin{array}{l}\text { 6. Design Authority/ Design Agent/Cog } \\
\text { Engr.: }\end{array}$ \\
Project, B\&W Hanford Company & C. D. (Dale) Eggen \\
\hline
\end{tabular}

8. Originator Remarks:

Approval and release.

4. Related EDT No.:

7. Purchase Order No.:

9. Equip./Component No.:

10. System/Btdg./Facjlity:

11. Receiver Remarks:

11A. Design Baseline Document? [] Yes [X] No

12. Major Assm. Dwg. Ko.:

13. Permit/Permit Application No.:

14. Required Response Date:

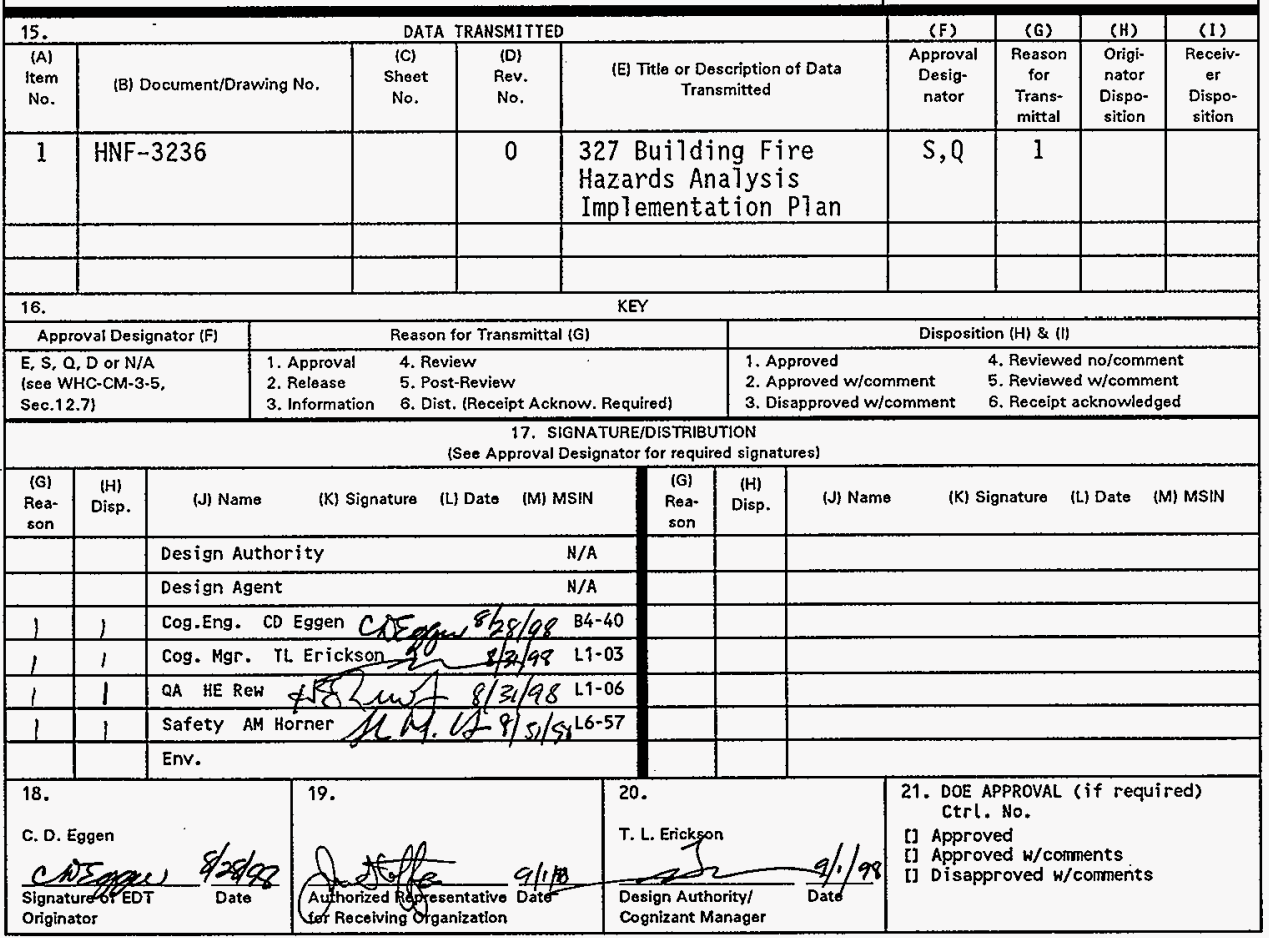

BD-7400-172-2 (05/96) GEF097 


\section{Building Fire Hazards Analysis Implementation Plan}

\section{D. Eggen}

B\&W Hanford Company, Richland, WA 99352

U.S. Department of Energy Contract DE-AC06-96RL13200
EDT/ECN: 623094
Org Code: 19210
UC: 2050
B\&R Code: EW7002010
Charge Code: HAN98200/K4M11
Total Pages: 9

Key Words: 327 Building, Fire Hazards, Analysis, Implementation Plan

Abstract: BWHC will use this Implementation Plan to bring the 327 Building into compliance with DOE Order $5480.7 \mathrm{~A}$ and RLID 5480.7 .

TRADEMARK DISCLAIMER. Reference herein to any specific commercial product, process, or service by trade name, trademark, manufacturer, or otherwise, does not necessarily constitute or imoly its endorsement, recommendation, or favoring by the United States Government or any agency thereof or $i$ ts contractors or subcontractors.

Printed in the United States of America. To obtain copies of this document, contact: Document Control Services, P.0. Box 950, Mailstop H6-08, Richland WA 99352, Phone (50́9) 372-2420; Fax (509) 376-4989.

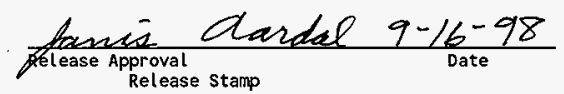

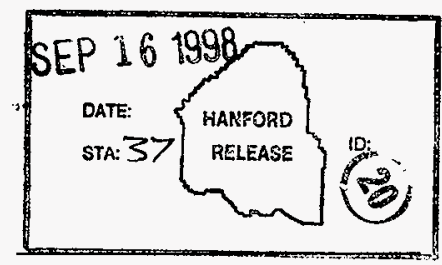

\section{Approved for Public Release}


HNF-3236, Rev. 0

\section{Building Fire Hazards Analysis Implementation Plan}

August 1998

prepared for:

United States Department of Energy, Richland Operations Office Richland, Washington

prepared by:

B\&W Hanford Company 
HNF-3236, Rev. 0

\section{EXECUTIVE SUMMARY}

In March 1998, the 327 Building Fire Hazards Analysis (FHA) (Reference 1) was approved by the U.S. Department of Energy, Richland Operations Office (DOE-RL) for implementation by B\&W Hanford Company (BWHC). The purpose of the FHA was to identify gaps in compliance with DOE Order 5480.7A (Reference 2) and Richland Operations Office Implementation Directive (RLID) 5480.7 (Reference 3), especially in regard to loss limitation. The FHA identified compliance gaps in five areas and provided nine recommendations (11 items) to bring the 327 Building into compliance. To date, actions for five of the 11 items have been completed. Exemption requests will be transmitted to DOE-RL for two of the items. Corrective actions have been identified for the remaining four items.

The completed actions address combustible loading requirements associated with the operation of the cells and support areas. The status of the recommendations and actions was confirmed during the July 1998 Fire Protection Assessment.

BWHC will use this Implementation Plan to bring the 327 Building and its operation into compliance with DOE Order 5480.7A and RLID 5480.7. 
HNF-3236, Rev. 0

\section{TABLE OF CONTENTS}

1.0 BACKGROUND AND PURPOSE $\ldots \ldots \ldots \ldots \ldots \ldots \ldots \ldots \ldots \ldots \ldots \ldots \ldots \ldots \ldots$

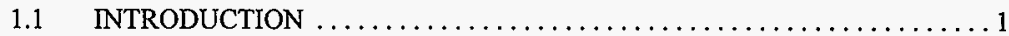

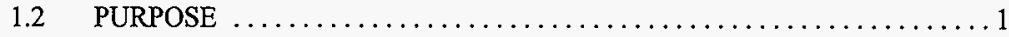

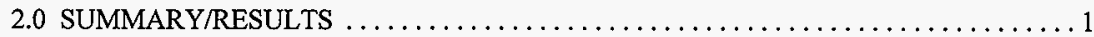

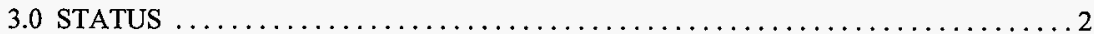

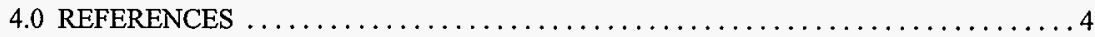


HNF-3236, Rev. 0

\section{TERMS}

BWHC

DOE

DOE-RL

ECN

FHA

HEPA

HVAC

LEL

MPFL

NFPA

PNNL

RLID
B\&W Hanford Company

U.S. Department of Energy

U.S. Department of Energy, Richland Operations Office

Engineering Change Notice

Fire Hazards Analysis

High-Efficiency Particulate Air

Heating, Ventilation, and Air Conditioning

Lower Explosive Limit

Maximum Possible Fire Loss

National Fire Protection Association

Pacific Northwest National Laboratory

Richland Operations Office Implementation Directive 
HNF-3236, Rev. 0

\section{BUILDING FIRE HAZARDS ANALYSIS IMPLEMENTATION PLAN}

\subsection{BACKGROUND AND PURPOSE}

\subsection{INTRODUCTION}

This report addresses corrective measures taken in order to implement the recommendations contained in the 327 Building Fire Hazards Analysis (FHA) (Ref. 1). The FHA was performed by Hughes Associates, Inc., under contract to B\&W Hanford Company (BWHC) in September 1997. The FHA was based on U.S. Department of Energy (DOE) Order 5480.7A, "Fire Protection" (Ref. 2), and Richland Operations Office Implementation Directive (RLID) 5480.7, "Fire Protection" (Ref. 3). This Implementation Plan provides a summary of the FHA recommendations and actions.

\subsection{PURPOSE}

The FHA was performed to analyze the loss potential of an accident in accordance with the guidelines contained in DOE Order 5480.7A and RLID 5480.7. The order and directive provide guidelines that are required to be reviewed. In addition, the order and directive require compliance with certain national codes and standards, such as the National Fire Protection Association (NFPA). The FHA documents the status of the facility at meeting the guidelines, codes, and standards, and provides recommendations to bring the facility into compliance.

This Implementation Plan addresses actions associated with each FHA recommendation to bring the 327 Building into compliance with DOE Order 5480.7A and RLID 5480.7.

\subsection{SUMMARY/RESULTS}

The FHA performed by Hughes Associates, Inc., was a comprehensive review of this facility as it was being transferred from operation and control of Pacific Northwest National Laboratory (PNNL) to BWHC.

The FHA for the 327 Building included nine recommendations which deal with the 327 Building operations. This plan outlines BWHC's actions for addressing the FHA recommendations. 
HNF-3236, Rev. 0

\subsection{STATUS}

The recommendations are shown as they appear in the FHA (Ref. 1) followed by the actions planned or completed for each recommendation.

1) Provide upgrades to the sprinkler system including the following:

(a) Provide supervised, indicating control valves for the sprinkler system. Basis: NFPA 13, Articles 2-7.1.1 and 4-14.1.1;

An expense funded Engineering Change Notice (ECN) has been prepared by Fire System Maintenance and will be implemented by Work Package 2G-97-3913. This work package will remove the control valves and bring the sprinkler system into compliance with NFPA 13, Articles 2-7.1.1 and 4-14.1.1. Completion of this work package will close out this part of the recommendation.

(b) Provide adequate heat tracing for the sprinkler systems potentially exposed to freezing conditions. Basis: NFPA 13, Article 4-14.4.1; and

Work Package 2G-97-3913 also includes a rework of the piping and the installation of dry sidewall heads. This will bring the sprinkler system into compliance with NFPA 13, Article 4-14.4.1. Completion of this work package will close out this part of the recommendation.

(c) Provide flexible pipe couplings. Basis: NFPA 13, Article 4-14.3.2.

Under the present configuration, a small earthquake could cause the plain end couplings on the piping to separate and allow water to flow into many areas of the facility. A scoping walkdown of the system was performed during the July 1998 Fire Protection Assessment. The engineering cost is estimated at $\$ 75,000$, which includes a detailed walkdown and design preparation. Construction is estimated at $\$ 100,000$ ( 20 couplings at $\$ 5,000$ each).

The 327 Building has a remaining life of approximately 8 to 10 years. It was concluded during the July 1998 Fire Protection Assessment that the installation of flexible pipe couplings to meet the requirements of NFPA 13, Article 4-14.3.2, will not significantly reduce the loss potential because of the low probability of a fire concurrent with an earthquake. Therefore, the expenditure of these funds is not prudent. An exemption request will be prepared by BWHC and transmitted to DOE-RL for its approval.

2) Maintain the current policies to limit explosive gases and combustibles/ flammable liquids introduced into the facility and into hot cells (e.g., limit exposure of sodium to water). The amount of combustible material in any air cell should not exceed the equivalent of $5 \mathrm{~kg}$ of hydrocarbon liquids (also includes plastics) or $27 \mathrm{~kg}$ of ordinary combustibles to prevent a cell fire from breaching the High-Efficiency Particulate Air (HEPA) filters. 
HNF-3236, Rev. 0

A combustible control program for the cells has been instituted in the 327 Building. Procedures such as 3M-SOP-PTL-179 control the amount of combustibles in all of the cells. A walkdown of the cells during the July 1998 Fire Protection Assessment determined that the combustible loading in the cells was within the limits of the above procedure. This action closes out this recommendation.

3) Ventilation in the cells handling flammable liquids and explosive gases should be assured of maintaining concentrations below 25 percent of the lower explosive limit (LEL) or explosion venting appropriate for the hazard should be provided in cells based on the enclosure strength and vent release pressure. Cell plugs exceed explosion venting vent closure weight criteria and also cause a projectile concern.

The completion of Recommendation 2 also completed this recommendation.

4) Provide hose outlets in the structure in accordance with DOE RLID 5480.7, 8.1.e. The current maximum possible fire loss (MPFL) does not anticipate fire department intervention and does not exceed allowable limits. Therefore, an exemption to not provide hose outlets could be merited. Particularly in light of the planned decommissioning and demolition activities.

An exemption request will be prepared by BWHC and transmitted to DOE-RL. This is consistent with the 327 Building FHA recommendation above.

5) Limit transient combustibles, such as wood pallets, rolls of plastic, or flammable or combustible liquids, around the switchgear area so the emergency power and normal power switches are not exposed to the same fire.

The completion of Recommendation 2 also completes this recommendation, which was verified during the July 1998 Fire Protection Assessment.

6) Remove storage from the exit access area to the loading dock. Basis: NFPA 101.

OR

Remove the exit sign identifying the loading dock as an exit.

This exit is not required as an emergency exit for the 327 Building personnel. Work Package 3M-98-00370 will remove the exit light and close out this recommendation.

7) Do not place combustibles, such as new or used HEPA filters and plastics, near the Heating, Ventilation, and Air Conditioning (HVAC) system. In particular, keep combustibles a minimum of 5 feet away from the HEPA filters in use.

The non-compliant materials found during the FHA Assessment have been moved, and the area within 5 feet of the HEPA filters is posted as non-storage. Further, the action taken to close out Recommendation 2 will help eliminate these types of problems in the future. Removal of the 
HNF-3236, Rev. 0

materials was verified during the July 1998 Fire Protection Assessment. Therefore, the action for this recommendation is completed.

8) Provide illuminated exit signs at the exit from the basement at the north stair and the decontamination area. Basis: NFPA 101.

Work Package 3M-98-00370 will install an exit sign and close out this recommendation.

9) Provide a redundant fire protection system within the building in accordance with DOE Order 5480.7A, 9.6.(1). Considering the MPFL, with the material at risk as provided by facility staff, the expenditure does not appear warranted for fire safety purposes and an equivalency or exemption is recommended.

The need for a redundant fire protection system is based on the MPFL being $\$ 50$ million or more. The MPFL for the 327 Building is about one-half of that figure. Therefore, a redundant fire protection system is not required for the 327 Building. This was confirmed with DOE-RL.

The action for this recommendation is complete. The elimination of the need for a redundant fire protection system for the 327 Building will be reflected in the next update of the 327 Building FHA.

\subsection{REFERENCES}

1. Hughes Associates, Inc., "327 Building Fire Hazards Analysis," HNF-SD-HT-FHA-003, Rev. 3, dated September 1997.

2. U.S. Department of Energy (DOE) Order 5480.7A, "Fire Protection."

3. Richland Operations Office Implementation Directive (RLID) 5480.7, "Fire Protection."

4. National Fire Protection Association (NFPA) 13, "Installation of Sprinkler Systems."

5. NFPA 101, "Life Safety Code." 


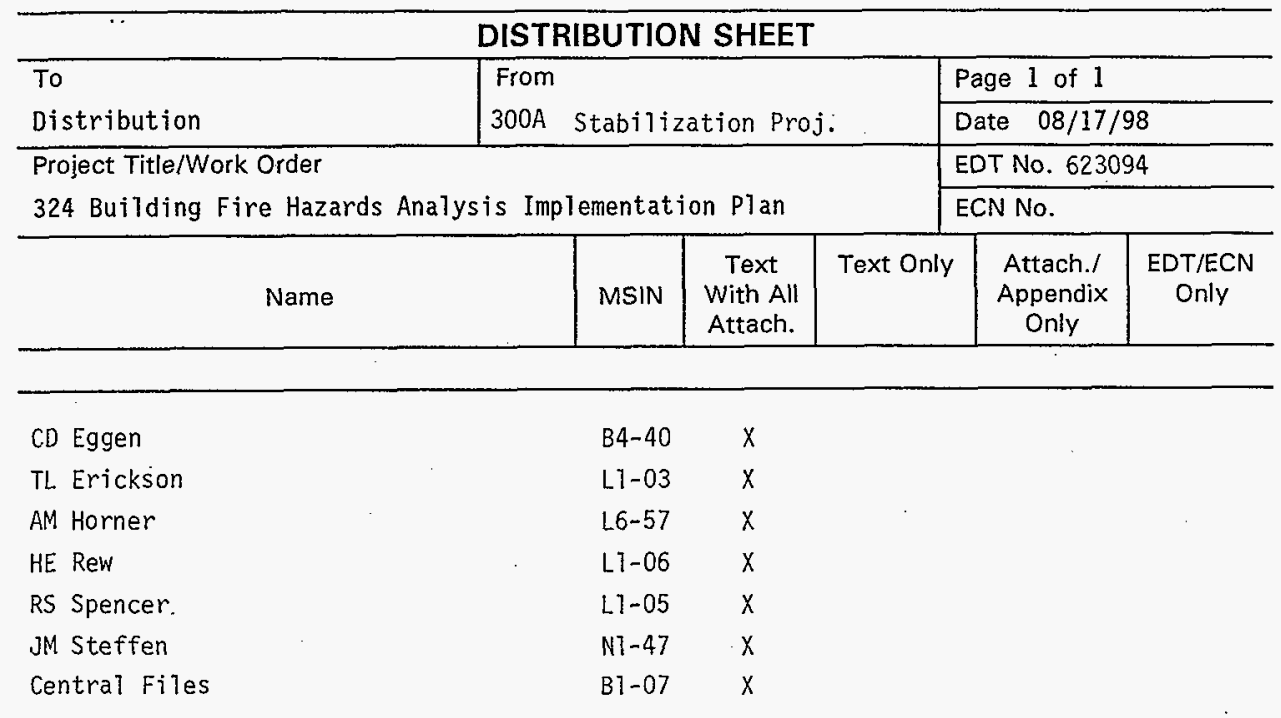

